\title{
Creating New Regions in Ghana: Populist or Rational Pathway to Development?
}

\author{
Ransford Edward Van Gyampo \\ Department of Political Science, University of Ghana \\ Email:vangyampo@yahoo.com \\ DOI//http://dx.doi.org/10.4314/gjds.v15i2.1
}

\begin{abstract}
The proposal for regional re-organisation and the creation of four additional ones seem feasible and has the needed popular support. Using archival sources and data from the IEA-VOTO Survey, the paper undertakes a thorough and detailed analysis of the processes leading to the creation of additional regions, and reveals imponderable challenges likely to be encountered. It argues that popular support for governmental policy proposals is not necessarily coterminous with feasibility, effectiveness and relevance. The paper therefore examines the feasibility and relevance of the proposal for the creation of additional regions in Ghana and proffers policy recommendations to re-focus the attention of policy makers on the critical challenges and barriers to rural development and how they could be effectively tackled.
\end{abstract}

Keywords: New Regions, Ghana; Campaign Promise, Cost, Development

\section{Introduction}

In the lead up to Ghana's 2016 General Elections, the flag bearer of the New Patriotic Party (NPP), Nana Akufo-Addo made several promises to Ghanaians. Notable among these promises is the creation of additional regions to ensure effective administration and the devolution of power (NPP Manifesto, 2016). Upon the assumption of power as the elected President of Ghana in January 2017, Nana Akufo-Addo gave indications that four (4) new regions would be created beginning from 2018 to bring the total number of regions in Ghana to fourteen. Per the campaign promise, the process towards the creation of a new region out of the current Western Region to be called the Western North Region is to be initiated. Again, on January 11, 2017 the president in a media report, hinted of the creation 
of three additional regions, namely the Ahafo out of Brong Ahafo Region, Oti out of Volta Region and a region out of the eastern corridor. ${ }^{1}$

In view of this, the president has created a new ministry known as the Ministry for Regional Re-organisation and Development, which is headed by Dan Kwaku Botwe, a Member of Parliament, to take full charge of the process. In spite of the commitment on the part of the government to create more regions, a number of Ghanaians continue to express some scepticism about the idea. Some have rejected it ab. initio while others are of the view that the proposal is completely misplaced given the urgent bread and butter issues, as well as basic challenges of development that confronts the people of Ghana. For instances, on $15^{\text {th }}$ January, 2017, a youth group in the Volta Region, the Concerned Volta Youth, kicked against the creation of a new region out of the existing one. According to Jean Claude Koku Amenyaglo, the convener and the spokesperson of the group, the region is too small in size and population to merit consideration for a split. He argued that citizens of the region are opposed to the initiative because it is needless and does not reflect their needs. He further noted that:

If the decision to split the region is as a result of lack of access to the regional capital, Ho by the districts, then the region needs good transportation systems like roads and rail, just as the president has established the Ministry of Railway [Development] so that we will have easy access to our regional capital. ${ }^{2}$

Several other Ghanaians have questioned the justification for the creation of new regions and indicated that it is a misplaced priority. Indeed, some have noted that if the increase of Districts from 110 through 170 to 216 could not deal with the challenge of rural poverty and under-development, it is unlikely that additional regions would serve similar purpose (IEA, Survey, 2017). The Gonja traditional council has also vowed to fiercely resist attempts to include portions of their land to the proposed eastern corridor region. ${ }^{3}$ Even though there is no media reportage of similar sentiments expressed against the region by chiefs and opinion leaders in other regions to be affected, apart from the sources above, Ghanaians remain somewhat divided over the relevance of additional regions.

1 For details, see http://3news.com/4-new-regions-to-be-created-starting-2018-nana-addo/

2 See details at http://pulse.com.gh/politics/new-regions-group-kicks-against-splitting-of-volta-regionid6059298.html.

3 See details athttp://zaaradio.com/local/gonja-traditional-area-warns-govt-over-splitting-of-northernregion/ 
What is the historical experience in the re-organisation and creation of regions in Ghana? What are the theoretical factors that favour the creation of new regions? Is there any justification for creating additional regions in Ghana? What are constitutional requirements for the creation of new regions in Ghana and what needs to be done to meet these requirements? How popular is the proposal? How feasible is the desire to create additional regions in Ghana? This paper seeks to proffer responses to the questions raised here and to provide policy recommendations to shape public policy, as well as guide the implementation of the proposal to create four additional administrative regions in Ghana.

\section{A Brief Note on Methodology}

The paper used secondary sources of data generated through archival research and information from the Institute of Economic Affairs (IEA)-VOTO Survey on the Expectations of Ghanaians of the New Government conducted in the first half of 2017. The IEA-VOTO Survey sampled the views of some 1,500 Ghanaians across the ten administrative regions of Ghana on their views on key government initiatives, interventions and policy proposals including the campaign promise to create additional regions in Ghana. ${ }^{4}$ The responses of respondents on the proposal to create new regions were used to support the analysis and claims of this paper.

\section{Regional Re-organisation and Creation of New Regions - A brief Historical Overview}

Regional re-organisation and creation of new regions in Ghana date back to colonial times. Politicians and policy makers have resorted to the practice so long as compelling reasons could be adduced. During the colonial era, in the then Gold Coast and around 1902, there were only three regions in Ghana. These were the Gold Coast Colony, the Ashanti Territory, and the Northern Protectorate. ${ }^{5}$ In 1956, TransVolta Togoland became a fourth region of Ghana after a plebiscite which sought the

4 The IEA-VOTO Survey was undertaken in March 2017. It sampled 1,500 respondents across the ten administrative regions of Ghana about their expectations of the new government. Part of the survey delved into the views and perceptions of Ghanaians about the proposal to create four additional administrative regions in the country. The IEA-VOTO Survey is a mobile phone interview session that reduces data collection time frames by weeks or months. Further the mobile phone method can easily gather very high sample sizes, enable a high frequency of data collection and always provides clean data. To conduct these interviews, a sampling method called Random Digit Dialing (RDD) was used to create the sample set for the survey.

5 Accra, Cape Coast and its environs constituted the Gold Coast Colony, while Kumasi and other areas in the Brong Ahafo Region constituted the Ashanti Colony. Again, the present day Northern, Upper East and Upper West regions were the Northern Protectorate. 
views of the people of Trans-Volta Togoland on whether they wanted to join Ghana at independence or be classified as part of Togo (Shillington, 1992; Austin, 1964; Chazan, 1974).

In 1957, following independence, the Gold Coast Colony was re-organised and divided into Eastern, Western, and Volta Regions. The Brong Ahafo Region was also carved out of the Ashanti Territory in the same year, while in 1960, the Upper Region was also created out of the Northern Territories. In 1970, the Central Region was created out of the Western Region while Greater Accra came out of the Eastern Region in 1982 via the Provisional National Defence Council Law 26. Finally, the Upper Region was re-organised and divided into the Upper East and Upper West Regions in 1983 (Shillington, 1992). Whereas some of these initiatives were done for effective and easy administration, as well as to create equitable development, others like the Brong Ahafo Region ${ }^{6}$ were whimsical, capricious and merely in fulfilment of campaign promises (ibid: 112). Similarly, the Upper Region, which was almost the same size as present Volta Region, was divided purely for whimsical political reasons - even though on face value, the move was ostensibly done in furtherance of Ghana's decentralisation?

\section{Regional Re-organisation: The Theoretical Justifications}

There are several scholarly works in the literature that offers some theoretical justifications for regional re-organisation and creation of new ones. For instance, it has been noted by some scholars that regionalism and the creation of additional regions are not arbitrary decisions made by politicians or policy makers (Mansfield and Milner 1997; Markusen 1983; Singh 1997). Scholars like Mansfield and Milner (1997) and Singh (1997) argue that such re-organisation is undertaken to meet specific needs of a growing population, protect minority ethnic or group interests and to ensure cohesion, as well as development that can tangibly be felt by all within a geographical polity. Though the creation of additional regional may be justified, Markusen (1983) argues for the cost implications to be analysed before the process is initiated. In the view of Singh (1997), countries that are relatively poor and under-developed must be aware of the budget implications of re-organising regions and creating extra ones to ensure that the exercise does not saddle nations with huge cost burden.

Ekweremadu (2012) is of the view that the reasons for such re-organisations may include the need for adequate development planning and equitable development;

6 I am grateful to the anonymous reviewer for this contribution.

7 See details at www.cwsa.gov.gh/cwsa_subcat_select.cfm? corpnews_catid=4\&corpnews_scatid $=18$ 
access to basic infrastructure; access to government; adequate representation and the need to ensure that each area has a sizeable and manageable population size. In fact, Kumado (2007) presents a similar argument suggesting that the creation of additional regions is justifiable when existing regions become bigger in terms of population size and outgrow the control of one minister. Kumado (2007) also supports the creation of additional regions when the chunk of a nation's resources meant to be distributed across the regions goes only to a few people in the regional capitals and surrounding towns much to the neglect of those who live in the hinterlands. Furthermore, he argues that some conflict situations, particularly those that have ethnic undertones, are sometimes generated by attempts by smaller ethnic groups to free themselves from the domination of the bigger ethnic groups within a region. This, according to Kumado (2007), sometimes fuel agitations for separate regions by ethnic groups that want to have some autonomy. He, however, warns of possible rippling effects of such agitations on other ethnic groups and stresses the need for measures to check unwarranted ethnic demands for regional re-organisation.

\section{A Political Justification?}

It has been argued that the current idea of creating new regions is not based on sound scientific policy but political expediency. ${ }^{8}$ A review of the explanations for the initiative seemingly points to this direction. First, the creation of additional regions was a campaign promise made by then Candidate Akufo-Addo during the 2016 electioneering campaign, which seems to have contributed to the electoral success of the ruling New Patriotic Party (NPP) in the general election. A review of the party's performance in the regions to be affected by the promise points to a positive correlation. ${ }^{9}$ Apart from this, some politicians in Ghana also believe in the theoretical justifications for the creation of additional regions. Justifying why there is the need for the creation of additional regions, President Akufo-Addo said "the process of devolution of power will require that we look again at the regional structures of our country all with the aim of trying to promote rapid development of Ghana."10

In an interview conducted by the author with Dan Botwe, the Minister of Regional Re-organisation and Development, in Accra on Wednesday $3^{\text {rd }}$ May 2017, he

8 I am grateful to the anonymous reviewer for this view. Indeed, it has been argued that if population size could influence regional re-organisation, then other populous regions like Ashanti and Greater Accra should also be re-organised.

9 See the website of the Electoral Commission of Ghana: www.ec.gov.gh

10 See details athttp://3news.com/4-new-regions-to-be-created-starting-2018-nana-addo/ 
explained that the proposal to re-organise regions and create additional ones hinges on several reasons including population growth, access to development, access to government, equitable distribution of national resources and increased representation of the people. He argued that the populations of several regions in Ghana have more than quadrupled since their creation. For instance, in 1960, the population of the Western Region was a little over 500,000 compared to its current size of over 2.3 million people according to the 2010 Population and Housing Census. This undermines effective representation. Again, some regions with fewer populations receive the same resources as regions with huge population in a manner that undermines equity in the distribution of national resources. For instance, the population of the Upper West Region is 2.8 percent of the total population size of Ghana, while that of the Ashanti Region is 19.4 percent; the Western Region accounts for 9.6 percent.

It has also been argued that many Ghanaians in the rural parts of the country are unable to access basic facilities such as hospitals, schools and other amenities that are often times located at the regional capitals and other towns closer to the capitals (IEA, Survey, 2017). In this regard, the re-organisation and creation of additional regions for those in the hinterlands would most likely lead to the provision of basic infrastructure and development projects that may be lacking. Last but not the least "it is necessary to re-organise and possibly create additional regions to give true meaning to the concept of representation in Ghana" (Botwe, 2017). According to Botwe (2017), additional regions would necessitate additional decentralised district assemblies within the regions to provide avenues for people's representation.

In addition, the Minister in charge of Regional Re-organisation and Development has claimed that the creation of the four additional regions is necessary to promote inclusiveness and effective representation of the people and that it is very difficult for populous regions to be effectively managed by regional ministers in a manner that creates a feeling of representation by the people.11 In as much as this may be true, the fact that heavily populous regions like Accra and Ashanti are not part makes the Minister's claim quite unsustainable.

11 See details at: http://pulse.com.gh/politics/vetting-dan-botwe-justifies-creation-of-new-regions-withghana-map-id613923o.html 


\section{Creation of Additional Regions: The Legal Framework}

The 1992 Constitution of Ghana provides the legal framework that serves as the basis for regional re-organisation and the creation of additional ones. Article 5 (1) states that the President may, by Constitutional Instrument -
a. Create a new region
b. Alter the boundaries of a region, or
c. Provide for the merger of two or more regions.

Clause 2 of same article says that "if the President, upon a petition being presented to him and, on the advice of the Council of State, is satisfied that there is a substantial demand for -
a. The creation of a new region;
b. The alteration of the boundaries of a region, whether or not the alteration involves the creation of a new region; or
c. The merger of any two or more regions;

s/he shall, acting in accordance with the advice of the Council of State, appoint a commission of inquiry into the demand and to make recommendations on all the factors involved in the creation, alteration or merger."

Clause 3 of article 5 of the same Constitution further states that "if, notwithstanding that a petition has not been presented to him, the President is, on the advice of the Council of State, satisfied that the need has arisen for taking any of the steps referred to in paragraphs (a), (b) and (c) of clause 1 of article 5, he may, acting in accordance with the advice of the Council of State, appoint a commission of inquiry to inquire into the need and to make recommendations on all the factors involved in the creation, alteration or merger". In clause 4 of article 5 , the Constitution states that "where a commission of inquiry appointed under clause 2 or 3 of same article finds that there is the need and a substantial demand for the creation, alteration or merger referred to in either of those clauses, it shall recommend to the President that a referendum (appropriately referred to as plebiscite in this instance) be held, specifying the issues to be determined by the referendum/ plebiscite and the places where they should be held."

In article 5(5), the President is mandated to refer the recommendations of the Commission of Inquiry to the Electoral Commission (EC) for a referendum/ plebiscite to be held in a manner prescribed by the EC. The constitution further states that for the plebiscite to be determined as successful, 50\% of citizens in the area where it is carried out must turn out and $80 \%$ of those who show up must vote 
in support of the issue that has been subjected to the plebiscite. Indeed, article 5(6) states that "an issue referred for determination by referendum under clauses 4 and 5 shall not be taken to be determined by the referendum unless at least 50\% of the persons entitled to vote cast their votes at the referendum, and of the votes cast, at least $80 \%$ were cast in favour of that issue." Why are all these constitutional provisions there? How do they affect the re-organisation and the creation of new regions?

\section{How Popular is the Proposal to Create Additional Regions?}

The proposal for regional re-organisation and creation of additional regions seems to be more of a campaign promise than a popular demand. Nevertheless, the Constitution provides the means by which a President, upon assessment of the nation's regional boundaries, may go ahead to create additional regions if he/ she finds it necessary. The question is, how popular is this proposal? The findings of the IEA-VOTO Survey questionably suggest a majority of Ghanaians support this proposal. ${ }^{12}$ Table 1 is a pictorial representation of the views of Ghanaians on the proposal for regional re-organisation and creation of additional ones.

Table 1: Popular views on the creation of new administrative regions

\begin{tabular}{|c|c|c|}
\hline \multicolumn{3}{|c|}{$\begin{array}{l}\text { The creation of new administrative regions in Ghana is necessary to } \\
\text { advance development }\end{array}$} \\
\hline Responses & Frequency & Percent \\
\hline Agree & 265 & 16.1 \\
\hline Disagree & 183 & 11.2 \\
\hline Strongly agree & 901 & 54.9 \\
\hline Strongly disagree & 292 & 17.8 \\
\hline Total & 1641 & 100.0 \\
\hline
\end{tabular}

Source: IEA VOTO Survey Data

Table 1 clearly shows popular support for the proposal as over $70 \%$ of the respondents gave some approval to it. Specifically, 54.9\% strongly agreed while $16.1 \%$ somewhat agreed. It must, however, be noted that while only $11.2 \%$ somewhat disagreed with the proposal, quite a sizeable $17.8 \%$ strongly disagreed. Table 2 shows similar support for the proposal across the ten administrative regions but in particular, the four main regions to be affected by the re-organisation, namely, Western, Brong Ahafo, Northern and Volta Region. Of the four regions identified for the split, the Brong Ahafo (59.9\%) and Western (59.6\%) respondents were more optimistic that the creation of new regions would facilitate development of their

12 See footnote 4 for details of the IEA 2017 Survey. 
regions. On the other hand, less than half of the respondents in the Northern $(44 \%)$ and Volta regions (46.6\%) strongly agreed that the creation of new regions would facilitate development of their regions. But, in the same Northern and Volta Regions, $20.1 \%$ and $\mathbf{1 2 . 0 \%}$ respectively agreed that the creation of new regions would somewhat lead to development. This is a clear indication of the general optimism and support of the proposal for regional re-organisation among the regions to be affected.

Table 1: Creation of new administrative regions - Citizens opinion by region

\begin{tabular}{|l|c|c|c|c|c|}
\hline Region & Agree & Disagree & $\begin{array}{c}\text { Strongly } \\
\text { agree }\end{array}$ & $\begin{array}{c}\text { Strongly } \\
\text { disagree }\end{array}$ & Total \\
\hline Ashanti & 15.9 & 11.3 & 60.3 & 12.5 & 100.0 \\
\hline Brong Ahafo & 12.6 & 9.6 & 59.9 & 18.0 & 100.0 \\
\hline Central & 16.8 & 12.1 & 55.0 & 16.1 & 100.0 \\
\hline Eastern & 10.2 & 13.8 & 61.1 & 15.0 & 100.0 \\
\hline Greater Accra & 19.1 & 9.6 & 52.5 & 18.8 & 100.0 \\
\hline Northern & 20.1 & 11.3 & 44.0 & 24.5 & 100.0 \\
\hline Upper East & 22.0 & 12.2 & 36.6 & 29.3 & 100.0 \\
\hline Upper West & 15.4 & 12.8 & 56.4 & 15.4 & 100.0 \\
\hline Volta & 12.0 & 13.5 & 46.6 & 27.8 & 100.0 \\
\hline Western & 19.3 & 8.3 & 59.6 & 12.8 & 100.0 \\
\hline Total & $\mathbf{1 6 . 1}$ & $\mathbf{1 1 . 2}$ & $\mathbf{5 4 . 9}$ & $\mathbf{1 7 . 8}$ & $\mathbf{1 0 0 . 0}$ \\
\hline
\end{tabular}

Source: IEA VOTO Survey Data

The point must be made that not many of the respondents knew what regional re-organisation entailed, yet they were fully in support of it largely because of the political goodwill enjoyed by the Akufo-Addo Government. In fledgling democracies, it is not unusual for the ordinary people to offer massive support for new regimes without sober introspection (Gyampo and Anamzoya, 2010; Tullock, 2002; Andersen, 1992). In this regard, the views of the close to $18 \%$ of respondents who disagreed with the proposal for regional re-organisation and the creation of new ones cannot be easily discounted. It is possible that many more may kick against the proposal after the "honeymoon" with the new regime. The next section discusses the feasibility of the proposal. 


\section{Analysing the Feasibility of the Proposal}

\section{The Analogy of Creating More Districts and Development}

What do the good people of the newly proposed regions in Ghana want? It is development - good roads, good schools, good health care, good drinking water, stable and affordable electricity, economic opportunity and jobs (IEA Survey, 2017). These can be provided through effective leadership and strong institutions without necessarily creating new regions (Acemoglu and Robinson, 2012). What is required is a paradigm shift in the thinking of politicians and policy makers. In the 1980s, there were 110 districts in Ghana. By 2006, an additional 28 districts were created by splitting some of the original 110, bringing their number up to 138. In February 2008, there were more districts created and some were upgraded to municipal status. This brought the final number to 170 districts in Ghana. Since June 2012, a further 46 districts have been added, bringing the total to 216 districts. If the idea of district re-organisation is to deepen decentralisation and promote rural development, is there any evidence to show transformation in the lives of the people with the increment of the number of districts from 110 to 216 ?

The lack of scientific evidence to show a correlation between new districts and development should be a warning to policy makers about the urgency and relevance of the proposal for regional re-organisation as it would also not necessarily lead to development. If additional districts could not lead to development, additional regions may not necessarily lead to development. Allocations from the District Assemblies Common Fund have been described as inadequate (Ayee, 2003). This explains why many districts are still wallowing in poverty and underdevelopment according to the 2015 District League Table. ${ }^{13}$ Any attempt at rural development must therefore target funding commitments to the districts first as the creation of more regions would not necessarily change the funding situation and commitments of the central government. In addition, the Assemblies do not have the required capacity to enhance development (ibid). For instance, they cannot even implement effective property tax administration to obtain the additional resources needed for their development (ibid). What will happen then is, with the new creation of regions and subsequent assemblies, the little capacity in terms of human resources in existence will have to be shared with such new ones, which will have a detrimental effect on the old assemblies.

13 The District League Table is a simple ranking tool developed by UNICEF and CDD-Ghana to track the performance of districts and national progress in terms of delivering developmental projects across the country's 216 districts. 
The United States has been a union of 50 states for many years. Alaska and Hawaii were the last two states to join the Union in 1959. Since then the USA has prospered and created wealth for its citizens. It has the most powerful armed forces in the world (Botwe, 2017). In contrast, Nigeria at independence in 1960 was a federal republic of 3 regions. In 1967, the regions were replaced with 12 states by the then military government by decree. Successive governments increased the number of states to the current 38 states and the Federal Capital Territory (Abuja). Most importantly the increase in the number of states in Nigeria has not delivered economic wellbeing and security to the ordinary Nigerian. It has rather become a huge drain on the national purse diverting resources from real economic and social development to maintaining the administrative machinery of state governments (Acemoglu and Robinson, 2012). Ghana should not travel that road. The US has its own problems with the 50 states. The fact that they are not "creating" new states does not mean all is well.

\section{Lessons from a Previous Attempt to Split the Northern Region}

Whilst campaigning for the 2008 general election, the then NPP presidential candidate Nana Akufo-Addo and the then NDC presidential running mate John Mahama both promised to split the Northern region into two at separate meetings with the late Yagbonwura Bawa Doshi (King of the Gonjas) at his palace in Damongo. This campaign pledge by the NPP and NDC was driven by a long-standing demand from the indigenes and residents of the Western part of the Northern region that development was skewed towards the Eastern part of the Northern region around the Tamale metropolis and the surrounding towns such as Savelugu, Walewale, and Yendi. ${ }^{14}$ Several youth associations in the region including the Gonjaland Youth Association made the partitioning of the region a recurring theme at their yearly meetings and congresses (Kumado, 2007; Hughes, 2017).

In October 2009, the Northern Region House of Chiefs presented a resolution for the creation of a new region to then Vice President Mahama at the Osu Castle. The principal arguments for this demand were accelerated development and administration efficiency, given the size of the Northern region and the fact that it covered about a third of the land mass of Ghana. This view had earlier been made by some past Northern Region ministers under both the Rawlings (1993-2000) and Kufuor (2001-2009) administrations (Gbana, 2017). Consequently, in 2009, the Mills administration set up a commission of inquiry into the splitting of the Northern region as a follow-up to the earlier demands (Gbana, 2017). Unfortunately, the

14 See details at http://m.myjoyonline.com/marticles/opinion/mr-president-rethink-creation-of-newregions 
report of the commission submitted to the President in 2010, was never released to the public (ibid). It is plausible to argue that the commission may not have established the case for splitting the region into two. Hence, the partitioning of the Northern region did not happen, but the agitations may have ceased because of a key intervention in January 2012.

The Mahama administration secured a \$166 million grant from the African Development Bank to construct the 147.5-kilometer Fufulso-Damongo-Sawla highway in the Northern Region that connects Fufulso on the Tamale-Kumasi road to Sawla on the Wa-Kumasi road (Gbana, 2017) ${ }^{15}$. The project, which was commissioned in August 2015 by President Mahama included the construction of market sheds, rehabilitation of schools and health facilities, water supply works (boreholes) and access roads to the highway. Its social and economic benefits have included increased access to markets for agricultural products, improved education and healthcare services, and reduction in transport costs for both goods and people. The highway has greatly improved accessibility to the major tourism sites in that corridor including the Mole National Park, the Larabanga Mystic Stone and Ancient Mosque, and the Gonja Kingdom Regalia (Gbana, 2017) ${ }^{16}$.

There are two key lessons from this story. First, a government does not need to create a new region or district to spread development. Second, agitations for new regions or districts will reduce if development is balanced within regions and districts in a manner that creates equal opportunities for all citizens. Indeed, accessibility to areas of a region and other parts of the country are also critical.

\section{The Legal and Constitutional Hurdles}

As discussed above, chapter two of the 1992 Constitution provides the requirement for the creation of new regions. The process as discussed could be long and costly. It begins with the submission of a petition to the President, or the President acting upon his own will. This is followed by the President setting up a commission of inquiry upon the advice of the Council of State. The commission will inquire into the need to create, alter or merge regions as the case may be and submit its recommendations to the President. If the commission establishes that the justification for doing so is inadequate that ends the discussion and the process would be discontinued. In other words, the President is powerless even if $s /$ he is willing to divide regions. But a cost would have been incurred as a result of the work of the commission. Even before the commission was set up, the Minister in charge of the proposal adopted an ingenious approach of consulting with the various

15 Interview with Hon Salifu Saeed, Northern Regional Minister, on $27^{\text {th }}$ September, 2017. 
chiefs and opinion leaders in the regions to be affected by the re-organisation to get their support (Botwe, 2017). This move, albeit commendable also comes with a cost to the state, which may be felt the most when the commission is unable to offer support for the proposal.

Where the commission establishes that there is adequate justification, it will recommend to the President to organise a referendum (plebiscite). The President will then refer the recommendations on the referendum (plebiscite) to the Electoral Commission, which will then decide on the mode and manner the referendum may be conducted. First, the plebiscite will only be binding if a minimum of $50 \%$ of eligible voters vote on the issue. Second, there is the issue of a minimum of $80 \%$ of those eligible voters voting to support the proposal. The whole process would become a nullity if these two main conditions are not met. Voter turnout in local elections since 1988 on the average has been about 30\% and, over the years, support for political parties has not transcended into voting during local elections. ${ }^{17}$ By law, political parties not in favour of a proposal are allowed to campaign against its implementation and given the potency of such campaign to be adversarial it may have a significant impact on voter turnout and consequently the result of such a referendum. The process must therefore be approached with caution and much introspection in order to avoid waste of time and effort.

\section{The Cost Involved}

As some scholars like Markusen (1983) and Singh (1997) have cogently argued, it may be costly in carrying out re-organisation of regions. Indeed, in Ghana, the cost involved in satisfying this constitutional process will be huge. It will include the establishment and funding of a secretariat for the Commission of Inquiry, sitting allowances and travel costs of Commission members, vehicles and fuel. If it gets to the stage of a referendum, the Electoral Commission will require money to organise the poll in the affected regions. If we succeed in creating new regions, we may further heap a huge cost burden on the tax payer as new regional administrations would have to be constructed and staffed. Again, new regional ministers and their deputies would have to be appointed and provided with juicy conditions of service that have been the subject of controversy in recent times. Indeed, in creating one region, the following are examples of the expenditure to be incurred:

- Hiring members of the commission of inquiry

- Referendum (plebiscite)

- Land acquisition

17 See details at www.ec.gov.gh 
- Building the regional administration

- Building the residency (including accommodation of the President)

- Vehicles

- Hiring staff such as regional coordinating directors, regional planners, administrators, etc

- Accommodation for staff

- Regional ministers and their deputies and their incentives/conditions of service.

Given these and other allied expenditure, the cost of creating one region may be estimated at about 10million USD. Also, it may cost up to 1million USD monthly to run a region so created. ${ }^{18}$ With a budget deficit of $9 \%$ of GDP as at 2017 , it may be quite difficult to commit resources to meet these costs or even justify such expenses on something that many consider as frivolous. If there is money it must be better spent in meeting the developmental needs of the people in the regions to be re-organised.

\section{Rippling Effect}

As argued by Kumado (2007), it is likely the creation of new regions may fuel agitation by others to demand same. Politicians should not be oblivious of the danger of possible demands and agitations from other regions of the country, which could potentially assume ethnic dimensions in a manner that may rather polarise the country. For instance, the Krobos may push hard to have their own region as separate from the Eastern Region. Similarly, it is possible that the Assins and Denkyiras in the Northern part of the Central Region may take a cue from the re-organisation of regions to also demand their own region. Policy makers must anticipate these likely rippling challenges and put in place measures to deal with them as advocated (Kumado, 2007).

\section{Conclusion and Policy Recommendations}

The proposal for regional re-organisation and the creation of additional ones seems feasible and has the needed popular support in spite of the imponderable challenges likely to be encountered. It must be noted that popular support is not coterminous with feasibility, effectiveness and relevance. Even if the challenges

18 Interview with the Head of Finance at the University of Ghana Business School, Professor Godfred Bokpin and interview with Professor Atsu Ayee, Political Scientist and Local Government Expert in Accra on Wednesday $17^{\text {th }}$ May, 2017. 
outlined are surmounted, the question that really ought to be answered relates to the essence of the proposal. What is the government seeking to achieve with this proposal? Fulfilling a campaign promise or achieving development for the people? As a developing country fighting to extricate ourselves from the quagmires of poverty and under-development, the focus of governmental policy initiatives must be towards the development of the people.

This paper argues that, in tackling the country's challenges, government must pay more attention and give meaning to effective decentralisation. Indeed, a decentralised governance system that thrives on direct election of Metropolitan, Municipal and District Chief Executives; allocation of adequate financial resources from central government and through internally generated funds; and the recruitment of qualified, as well as competent people to man the local assemblies are the rational pathways that can potentially lead to tangible development at the grassroots (Ayee, 2003).

It is important that campaign promises are fulfilled. However, such promises made out of sheer political expediencies must be reviewed more thoroughly and rationally after the campaign season is over. The real action of responding to local needs is at the district and certainly, not at the regional level. In this regards, the paper recommends that the District Assemblies must be well equipped to function better and become the real development agents especially with the promised additional resources of 1 million dollars per constituency per year. ${ }^{19}$

The government must also take a serious lesson from how its predecessor halted the agitation for the splitting of the Northern Region through the implementation of the Fufulso-Damongo-Sawla corridor project. This may be replicated in the regions that are currently candidates for re-organisation. It is this kind of infrastructure development and implementation of manifesto pledges like One District, One Factory; One Village, One Dam; that creates economic opportunity, jobs and social development that ordinary Ghanaians desire. In this regard, the creation of new regions may be a mere political luxury that can be shelved without hurting the image and future electoral fortunes of the ruling government.

19 See details of the 2016 Manifesto of the New Patriotic Party available at http://newpatrioticparty.org/ docs/2016-manifesto-full.pdf 


\section{References}

Acemoglu, D. and Robinson, J. (2012). Why nations fail: The origins of power, prosperity and poverty. 1st edition. New York: Crown.

Andersen, C.W. (1992). "Limited Government - A Moral Issue" available at www.fff. org/freedom/o292c.asp.

Ayee, J.R.A. (2003). "Decentralisation and local governance: The Ghanaian experience," in N. Amponsah and K. Boafo-Arthur (eds.) Local Government in Ghana, Livog Limited: Accra.

Austin, D. (1964). Politics in Ghana: 1946-1960. London: Oxford University Press.

Botwe, D. (2017). Author's interview with Dan Botwe, the Minister in Charge of Regional Re-organisation and Development in Accra on $4^{\text {th }}$ May 2017.

Chazan, N. (1974). "Politics and youth organisations in Ghana and Ivory Coast", Unpublished PhD Thesis Submitted for Doctorate Degree to the Senate of the Hebrew University of Jerusalem, Israel, pp.2-210.

Ekweremadu, I. (2012). Restructuring, states creation and the accompanying delusions available at: http://www.vanguardngr.com/2012/o3/restructuringstates-creation-and-the-accompanying-delusions/.

Gbana N. (2017). "Rethink creation of new regions" available at http://m.myjoyonline. $\mathrm{com} / \mathrm{marticles} /$ opinion/mr-president-rethink-creation-of-new-regions.

Gyampo, R.E.V and Anamzoya, A.S. (2010). Ministerial appointments and government expenditure in developing democracies: A case study of Ghana's Fourth Republic. Journal of Arts and Education (June) Vol. 4. No. 1, pp. 49-73.

Institute of Economic Affairs (2017). Survey on peoples' expectations of the new government. Accra: IEA.

Kumado, K. (2007). “The degree of our commitment to our national motto - Freedom and Justice: An Assessment", A Ghana at 50 Lecture Delivered in Accra on Wednesday, $30^{\text {th }}$ March.

Mansfield, E. and Milner, H. (1997). The political economy of regionalism. New York: Columbia University Press.

Markusen, A. (1983). Regions and regionalism. The Hague: Springer.

Shillington, K. (1992). Ghana and the Rawlings Factor. London: Macmillan.

Singh, A. (1997). Regionalism in Indian Politics. New Delhi: Radha Publications.

Tullock, G. (2002). Government failure: A Premier in public choice. Washington DC: Cato Institute. 